\title{
TUTELA PENAL DO DESCARTE DE ORGANISMOS GENETICAMENTE MODIFICADOS: UMA ANÁLISE DO ARTIGO 27 DA LEI DE BIOSSEGURANÇA
}

\author{
Daniel Alberico Resende ${ }^{1}$ \\ Camila Gomes de Queiroz ${ }^{2}$
}

RESUMO: O objetivo deste artigo é analisar o descarte de organismos geneticamente modificados à luz do artigo 27 da Lei de Biossegurança. Será exposta, ainda, a relação da bioética com os OGMs. Concluiu-se que as condutas elencadas no artigo 27 da referida lei federal são fruto de técnica legislativa voltada à tipificação de crimes de perigo abstrato, dispensando-se a demonstração concreta de lesão ou perigo de lesão ao bem jurídico tutelado, em manifesta violação ao princípio da ofensividade. Foi utilizado o método jurídico exploratório, a partir de análises em fontes bibliográficas e documentais.

Palavras-chave: Bioética; organismos geneticamente modificados; Lei Federal $\mathrm{n}^{\circ}$ 11.105/2005; descarte; tutela penal.

\section{CRIMINAL PROTECTION FOR THE DISPOSAL OF GENETICALLY MODIFIED ORGANISMS: AN ANALYSIS OF ARTICLE 27 OF THE BIOSAFETY LAW}

ABSTRACT: The aim of this article is to analyze the disposal of genetically modified organisms in light of article 27 of the Biosafety Law. The relationship between bioethics and GMOs will also be exposed. It was concluded that the conducts listed in article 27 of the aforementioned federal law are the result of a legislative technique aimed at typifying crimes of abstract danger, dispensing with the concrete demonstration of injury or danger of injury to the protected legal interest, in manifest violation of the principle of offensiveness. The exploratory legal method was used, based on analyzes in bibliographic and documentary sources.

Keywords: Bioethics; genetically modified organisms; Federal Law No. 11.105/2005; disposal; penal protection.

\section{INTRODUÇÃO}

A premência na aproximação dos estudos acerca da medicina e suas técnicas basilares é uma presunção imperiosa ao condizente tratamento das indagações em ascensão,

\footnotetext{
${ }^{1}$ Mestrando em Direito Ambiental e Desenvolvimento Sustentável pela Escola Superior Dom Helder Câmara (ESDHC). Especialista em Direito Ambiental pela Faculdade Internacional Signorelli. Especialista em Direito Notarial e Registral pela Damásio Educacional. Bacharel em Direito pelo Centro Universitário Presidente Tancredo de Almeida Neves (UNIPTAN).

${ }^{2}$ Mestranda, com área de concentração em Instituições Sociais, Direito e Democracia pela Fundação Mineira de Educação e Cultura (FUMEC). Mestranda em Direito Ambiental e Desenvolvimento Sustentável pela Escola Superior de Direito Dom Helder Câmara (ESDHC). Especialista em Direito Ambiental e Minerário pela Pontifícia Universidade Católica de Minas Gerais (PUC-MG). Bacharel em Direito pela Pontifícia Universidade Católica de Minas Gerais.
}

Revista de Biodireito e Direito dos Animais | e-ISSN: 2525-9695 | Encontro Virtual | v. 7 | n. 2 |

p. $01-16$ | Jul/Dez. 2021. 
especialmente as advindas das tecnociências. Nesse esteio, a bioética data da metade subsequente do século XX em razão de considerável avanço tecnocientífico, bem como das vultuosas transformações coletivas da sociedade e dos institutos políticos que estimularam alterações nas interrelações sociais.

Dessa forma, amplia-se no transcurso do século XX a fixação de um mecanismo de valoração para solução de questões éticas advindas das inovações e ingerências biotecnológicas. Já no século XXI, tal questão adentra encarando paradoxos deontológicos, dos quais até o momento não entreviu-se, em tese e em rápida análise, respostas globais, e baseia-se numa percepção plural e dialogal, o que, constantemente, incute uma interlocução com o direito.

Denota-se, ainda, que, no sentido bioético, a multidisciplinaridade leva à convergência de temáticas substancialmente distanciadas reciprocamente e de difícil domínio por apenas um conhecedor: a análise a respeito das questões ambientais ou acerca da conceituação de morte, por exemplo, de modo objetivo, requer conhecimentos amplamente locucionados e demarcados para enfrentar tal questão.

Nessa esteira, o problema a ser enfrentado consiste em analisar, com a progressão dos debates e das pesquisas, como eventuais inquietações se apresentaram e sistematizaram modernos rumos para as discussões bioéticas e como essas ideias e potenciais módulos teóricos abarcam inúmeras correntes éticas, que, eventualmente, podem vir a impactar na acepção de bioética e, consequentemente, de biodireito.

Partiu-se da hipótese que, paulatinamente, filósofos inauguraram o interesse pela esfera da ética voltada para questões biomédicas e, diante desse interesse, iniciou-se o alargamento da disciplina ética normativa, consolidada no que atualmente se chama de "bioética".

Por essas razões, o objetivo central do presente trabalho é verificar se ao direito incube trazer resoluções jurídicas aos choques bioéticos, no intuito de defender o indivíduo em sua totalidade, assentando uma sistemática de preceitos e convicções que sejam recebidos como globais e de caráter vinculativo.

O presente trabalho se justifica em razão da contemporaneidade do assunto, além de possuir espeque na interação entre direito e bioética, tendo em vista o enfoque comum, que abarca a relevância da existência em suas diversas dimensões os ramos da tecnociência, bem como a esfera biomédica e suas reverberações. 
No decorrer do texto será apresentado o conceito de bioética e como este se relaciona com a tipificação de organismos geneticamente modificados presente da Lei de Biossegurança. Além disso, será efetuada exaustiva análise do referido tipo penal, de forma que se verifique se o caráter ultima ratio inerente ao Direito Penal é suficiente para garantir a proteção de OGMs.

Nessa linha, a discussão proposta nesse trabalho, fundamentada numa análise bibliográfica de modo crítico, é a reflexão acerca da Lei Federal no 11.105 , promulgada em 24 de março de 2005, que estabelece normas de segurança e mecanismos de fiscalização sobre, dentre outros temas, a liberação no meio ambiente e o descarte de organismos geneticamente modificados - OGM e seus derivados. Neste contexto, o artigo 27 da norma tipifica criminalmente a liberação ou descarte de OGM no meio ambiente, em desacordo com as normas estabelecidas pela CTNBio e pelos órgãos e entidades de registro e fiscalização.

Apesar da tipificação na lei, discute-se a violação do princípio da ofensividade por parte do referido tipo penal. Diante disso, este estudo pretende analisar brevemente a administrativização do direito penal na tutela do descarte de organismos geneticamente modificados no meio ambiente, a partir da criminalização da conduta prevista no artigo 27 da Lei 11.105/05.

A presente pesquisa é de método hipotético-dedutivo. Em relação à abordagem do problema, o estudo é de natureza qualitativa. Os objetivos deste estudo se classificam como descritivo e explicativo. Por fim, em relação às técnicas de coleta, serão utilizadas pesquisa documental, especialmente a Lei $\mathrm{n}^{\mathrm{o}} 11.105 / 05$, bem como pesquisa bibliográfica, utilizando livros e artigos científicos, além de o marco teórico ser o artigo científico intitulado “Implementação da Lei de Biossegurança no Brasil”, por Silva, Pelaez e Valle.

\section{BIOÉTICA E ORGANISMOS GENETICAMENTE MODIFICADOS}

Embora distingam-se em seus horizontes, não existe uma contraposição entre as influências mútuas, sendo o ponto primordial de intercessão a dignidade da pessoa humana. Nessa conjuntura, afirma Casabona que num desfecho, a bioética pretende, auxiliar o direito com direcionamentos nessa área. Contudo, para o autor, esse pacto é mais amplo, visto que desvela contribuições com critérios nítidos, incialmente sem ambiguidades, e legitimo para a proposição de soluções em casos concretos (CASABONA, 2005, p. 27). 
Ainda sob a ótica do autor, o debate entre bioética e direito deve ter por preceitos inabdicáveis: 1) a reflexão acerca dos valores regulamentadores e sua implementação; 2) a asseguração do pluralismo no debate; 3 ) a perquisição do alinhamento de critérios, ademais na esfera que transcende o nacional e internacional, equilibrando os regulamentos; e 4) a ingerência do direito com múltiplos focos: o aparelhamento jurídico deve ser cauteloso e sóbrio, elástico e aberto a convicções e circunstancias variadas.

O estreito relacionamento entre bioética e direito é, por conseguinte, nítido, mas os respectivos ordenamentos normativos se distinguem. $\mathrm{O}$ direito, como ordenamento pragmático de resolução de embates, pode ser analisado por um horizonte dogmático. Contudo a moral, tem sua atuação no âmbito jurídico, como regulamento normativo assessor, fornecendo subsídios para a construção e eficácia do direito, todavia, sem com ele se enredar. A bioética, desse modo, é relevante para o direito, pois participa da zetética jurídica (SÁ, NAVES, 2021, p. 9).

$\mathrm{Na}$ conjuntura atual, o conhecimento jurídico não pode ser colocado em um papel simplesmente instrumental, dominado por debates bioéticos que preterem na sobreposição da honradez e, inclusive a religião, ante a carências sociais e jurídicas. O direito preza pelo acatamento à autodeterminação individual e ascensão dos grupos, pela abstenção dos agravos contra o indivíduo, salvaguardando a existência humana como ingerência da inata dignidade.

O biodireito apresenta como finalidade precípua a estruturação de perspectivas jurídicas atuais em relação a temáticas tão antigas quanto o próprio conhecimento humano: tais como a existência (vida e morte), a perfilhação e fertilidade, saúde física e psíquica e autodeterminação. Ademais, apresenta como objetivo, a identificação de concepções éticas e sociais atuais, necessárias para resolver as questões em ascensão abarcadas pela genética, medicina, bioquímica, telemática, biologia, biofísica etc. O panorama é único: o indivíduo como interlocutor e favorecido por direitos e defesas resultantes da norma. Sua fundamentação individual é a dignidade da pessoa humana, vista não só como uma opção moral, mas de sobremodo protegido e promovido como pressuposto jurídico.

Registre-se que para o assentimento do biodireito como preceito científico autônomo deveria se aglutinar num monismo metodológico, em questionamentos empíricos e nas mesmas regras operacionais das ciências naturais seria postergar o fato de que existem outras maneiras de construir conhecimento científico atualmente (JONSEN, 1998, p. 345). 
O monologismo do dogma jurídico é módico para aperceber-se da complexidade manifesta pelas questões bioéticas. A inexistência de codificação ou legislação unificadora ainda não é suficiente para garantir que o biodireito não se consolida como conceito de normas de caráter protetivo e que abarca múltiplas áreas do saber jurídico com caracteres, base e valores intrínsecos. Assim, Casabona arremata que:

[...] para esta consideração de autonomia não constitui obstáculo que o direito biomédico não seja, todavia, objeto de ensino independente, nem que seus embasamentos conceituais sejam importados das disciplinas jurídicas fundamentais tradicionais, pois se distancia e separa destas tanto pelo objeto específico de seu estudo como pela metodologia própria que o caracteriza; como foi indicado, há de consistir em uma aproximação jurídica integrada, sem prejuízo que tome, como ponto de partida, uma perspectiva interdisciplinar e multidisciplinar (CASABONA, Carlos, 2005,p.17).

Logo, o sistema do biodireito, enquanto regramento normativo, é categórico, tendo seus preceitos um caráter de prescrição. O paradigma apresentado pelo biodireito é de justiça - não apenas como pressuposto ético, mas também como argumento estratégico e tomado numa visão filosófica - da qual as regras devem conter múltiplos e relevantes preceitos destinados à defesa plena do ser humano baseados em direitos humanos e valores fundamentais que, em caso de conflito, sejam sanados mediante um caso concreto.

Acerca da questão, Fabriz assevera que o biodireito mostra suas origens arraigadas as raízes dos direitos fundamentais e, nessa matéria, deles se faz inseparável. O biodireito engloba os direitos deontológicos correlatos à vida, à dignidade e à privacidade dos sujeitos, manifestando a transposição do debate adornado de eticidade para a ordem jurídica, não tendo potencial de:

[...] constituir uma mera legitimação jurídica de valores designados por sábios, ou ainda que promulgado por um legislador religioso ou moral. $\mathrm{O}$ biodireito presume a elaboração de uma classe intermediária, que se corporifica nos direitos humanos, garantindo os seus fundamentos racionais e legitimadores. (FABRIZ, 2003, p.288)

Noutro giro, em razão da velocidade das inovações biotecnológicas, o direito que não tem a pretensão de manifestar termos únicos, mas soluções que tenham escopo de se erigirem em virtude de um caso factual, não se restringindo a retórica legal ou ao simples discurso positivista. Dessa forma, o biodireito tem como objetivo a organização de condutas na entidade biotecnológica, intencionando respeito e elevação de princípios que norteiam a raça humana, ordenando a autodeterminação e instruindo para a conservação valores primordiais. 
O biodireito intenta a organização de condutas na entidade biotecnológica, intencionando respeito e elevação de princípios que norteiam a raça humana, ordenando a autodeterminação e instruindo para a conservação valores primordiais. Ademais, ele não deve ser abordado como prisma estrangeiro, como ramo não científico alheio aos dogmas jurídicos. Pelo contrário, o biodireito deve ser estabelecido como matéria autônoma, com metodologia própria, aglutinadora de demais disciplinas consideradas convencionais, mas que tem o condão de contribuir para sua robustez, com a estruturação de uma locução intrínseca com aptidão de satisfazer sua natural multidisciplinaridade.

A distinção entre direito e ética, está na reconstrução histórica, na secularização e na multiplicidade deontológica da bioética e ademais na identificação do próposito do biodireito que possibilita assegurar que ele é uma nova face do ramo do saber que suscita metodologia e embasamento próprios, com escopo de lhe conceder a condição de preceito acadêmico na rota da tão almejada multidisciplinaridade. Daí advém a reflexão acerca da assertiva de Garrafa, que sobre o biodireito constatou:

O neologismo que estão tentando implantar, chamado 'biodireito', é um aleijão. Se a
bioética já veio como uma nova disciplina e requer um pouco de cada uma e a sua
grande força é a multidisciplinaridade, imaginem se começam com a biofilosofia; a
bioeconomia; a biomedicina; a biologia; a biopsicologia? Não é essa a concepção.
Há o perigo de usar esse modismo - que é francês, para variar, mas não significa que
a França não esteja trabalhando seriamente. Nos países que estão atuando seriamente
nessa área - a Inglaterra, por exemplo - o grande tema é bioética e direito, bioethics
and law. Essa questão, ao ser reduzida, ficará compartimentalizada, e não é essa a
ideia inicial. Faço um apelo para as pessoas que estão querendo colocar a palavra
'biodireito' na rua que pensem duas ou três vezes. Se 'biodireito' significar o direito
trabalhando as questões biotecnológicas, concordo, mas se significar o 'biodireito'
com respeito à bioética, discordo flagrantemente e digo que isso é uma impureza
conceitual e um erro metodológico e epistemológico grave (SANTOS, Maria
Celeste, 2001, p.120).

Ao se atribuir ao biodireito uma evolução de esfera autônoma, cogita-se a estruturação de um biodireito, que defenda permanentemente a dialógica entre direito e bioética, conservando-se a maleabilidade intrínseca entre eles. Com o intento de se estabelecer suas ideologias, premissas, metodologias, salvaguardando sua multiplicidade principiológica.

\section{ORGANISMOS GENETICAMENTE MODIFICADOS E A PREVISÃO DE DESCARTE}


Os organismos geneticamente modificados (OGM) são definidos, sob o aspecto legal, como "organismo cujo material genético - ADN/ARN tenha sido modificado por qualquer técnica de engenharia genética" (BRASIL, 2005). Não obstante os OGM, a lei ainda prevê os derivados de OGM, que são o "produto obtido de OGM e que não possua capacidade autônoma de replicação ou que não contenha forma viável de OGM.” (BRASIL, 2005).

De acordo com Pessoa (2009, p. 54), "produtos transgênicos ou organismos geneticamente modificados (OGMs) são todos aqueles que recebem, in vitro, um ou mais genes." Sob o ponto de vista doutrinário, CAPALHO et al (2009, p. 193) aduzem que "sendo o OGM um organismo vivo, ele pode se dispersar, colonizando novos ambientes, requerendo por isso uma abordagem distinta daquela aplicada para produtos químicos (agrotóxicos em especial)." Diante disso, surge a necessidade de um descarte específico com vistas a impedir eventuais danos ao meio ambiente.

De forma geral, o descarte de resíduos sólidos é disciplinado pela Lei Federal 12.305 de 2 de agosto de 2010, que, dentre outras providências, institui a Política Nacional de Resíduos Sólidos. Contudo, no caso dos OGM, a Resolução nº 18, de 23 de março de 2018 do CTNBIO estabelece a classificação de riscos de Organismos Geneticamente Modificados (OGM) e os níveis de biossegurança a serem aplicados nas atividades e projetos com OGM e seus derivados em contenção que influenciarão no seu descarte.

De acordo com a referida resolução, os OGM são classificados em quatro classes de risco, de acordo com o potencial patogênico dos organismos doador e receptor, a(s) sequência(s) nucleotídica(s) transferida(s), a expressão desta(s) no organismo receptor, o potencial patogênico da(s) proteína(s) codificadas pelo(s) gene(s) do organismo doador. Além disso, quando conhecido, o OGM resultante e seus efeitos adversos à saúde humana e animal, aos vegetais e ao meio ambiente.

Nessa perspectiva, o artigo $8^{\circ}$ da Resolução em comento dispõe que os OGM de classe 1 são aqueles com baixo risco individual e baixo risco para coletividade. Já os de classe de risco 2 possuem risco individual moderado e baixo risco para a coletividade, enquanto os de risco 3 possuem alto risco individual e risco moderado para a coletividade. Por fim, os de classe de risco 4 possuem alto risco individual e alto risco para a coletividade.

Conforme já afirmado alhures, a classificação dos OGM impactará na forma como o resíduo será manuseado e descartado no meio ambiente. De forma ampla, essa classificação também pretende cumprir os objetivos da Política Nacional de Resíduos Sólidos, em especial 
o princípio da proteção da saúde pública e da qualidade ambiental, previsto no artigo $7^{\circ}$, inciso I, da Lei Federal 12.305/10.

Ressalta-se que, como exposto por Naves e Silva (2014, p. 361), “a propagação de certos efeitos toxicológicos no meio ambiente pode ocorrer em cadeia, em virtude da natureza da relação que os organismos estabelecem entre si e com o próprio ecossistema”. Diante disso, surgiram na Lei 11.105/05 mecanismos que visam coibir o lançamento inadequado de OGM no meio ambiente.

De forma a explicitar a temática central do presente estudo, no tópico a seguir trabalhar-se-á a Lei 11.105 de 2005 e a forma como disciplina as normas de segurança e os mecanismos de fiscalização de atividades que envolvem os OGM. Dessa forma, será possível analisar a administrativização do direito penal na lei em comento.

\section{A LEI 11.105/05 E A TUTELA DO MEIO AMBIENTE}

Como exposto no capítulo anterior, é necessário se ater à preservação do meio ambiente na utilização de organismos geneticamente modificados. Diante disso, promulgouse, em 2005, a Política Nacional de Biossegurança, que "teve como motivação principal o estabelecimento de um marco regulatório que pudesse pôr fim às indefinições e às controvérsias que marcaram os litígios judiciais iniciados em 1998" (SILVA; PELAEZ; VALLE, 2009, p. 89).

Noutro giro, Oliveira (2016, p. 125) sustenta que a Lei Federal 11.105 de 2005, “fora elaborada para a satisfação de interesses de transnacionais, a exemplo da Monsanto e agricultores que conseguiram, de maneira irregular (contrabando), introduzir em solo pátrio sementes de soja geneticamente modificadas (Roundup ready).”

De forma sintética, a Política Nacional de Biossegurança, em seu artigo $8^{\circ}$, criou o Conselho Nacional de Biossegurança, cujas competências principais são fixar princípios e diretrizes para a ação administrativa dos órgãos e entidades federais com competências sobre a matéria, analisar, a pedido da CTNBio, quanto aos aspectos da conveniência e oportunidade socioeconômicas e do interesse nacional, os pedidos de liberação para uso comercial de OGM e seus derivados. Por fim, avocar e decidir, em última e definitiva instância, com base em manifestação da CTNBio e, quando julgar necessário, dos órgãos e entidades referidos no 
artigo 16 da mesma lei, no âmbito de suas competências, sobre os processos relativos a atividades que envolvam o uso comercial de OGM e seus derivados.

Ademais, houve a criação da Comissão Técnica Nacional de Biossegurança CTNBio, para prestar apoio técnico e de assessoramento ao Governo Federal na formulação, atualização e implementação da PNB de OGM e seus derivados. Ademais, auxiliar no estabelecimento de normas técnicas de segurança e de pareceres técnicos referentes à autorização para atividades que envolvam pesquisa e uso comercial de OGM e seus derivados, com base na avaliação de seu risco zoofitossanitário, à saúde humana e ao meio ambiente.

Ademais, não obstante a previsão constitucional da tríplice responsabilidade ambiental, conforme artigo 225, $\S 3^{\circ}$, da Constituição da República Federativa do Brasil de 1988 (CRFB/88), a lei trata de maneira expressa sobre a responsabilidade ambiental. As responsabilidades civil e administrativa estão previstas, respectivamente, nos artigos 20 e 21 da lei:

Art. 20. Sem prejuízo da aplicação das penas previstas nesta Lei, os responsáveis pelos danos ao meio ambiente e a terceiros responderão, solidariamente, por sua indenização ou reparação integral, independentemente da existência de culpa. Art. 21. Considera-se infração administrativa toda ação ou omissão que viole as normas previstas nesta Lei e demais disposições legais pertinentes. (BRASIL, 2005)

Sob o ponto de vista criminal, há tipificação nos artigos 24 a 29, sendo crimes as seguintes condutas: utilizar embrião humano em desacordo com a Lei, praticar engenharia genética em célula germinal humana, zigoto humano ou embrião humano, realizar clonagem humana, liberar ou descartar OGM no meio ambiente, em desacordo com as normas estabelecidas pela CTNBio e pelos órgãos e entidades de registro e fiscalização. Ademais, utilizar, comercializar, registrar, patentear e licenciar tecnologias genéticas de restrição do uso e produzir, armazenar, transportar, comercializar, importar ou exportar OGM ou seus derivados, sem autorização ou em desacordo com as normas estabelecidas pela CTNBio e pelos órgãos e entidades de registro e fiscalização.

Pelo exposto, constata-se que há uma preocupação do legislador em preservar o meio ambiente ecologicamente equilibrado. Contudo, é necessário verificar se a tipificação das condutas feitas pelo legislador observou os critérios e princípios que regem a teoria do delito, no tópico seguinte analisar-se-á o tipo penal previsto no artigo 27. 


\section{TUTELA PENAL DA OGM E O ARTIGO 27 DA LEI No 11.105/2005}

Foi a Constituição da República Federativa do Brasil de 1988 que impôs, inicialmente, ao poder público o dever de preservação da biossegurança e da integridade do patrimônio genético do país, por meio dos incisos II, IV e $\mathrm{V}$ do artigo 225. Para regulamentar as obrigações do poder público, o legislador editou a Lei $n^{\circ}$ 8.974/95, que, posteriormente, foi revogada pela Lei $\mathrm{n}^{\circ} 11.105 / 05$, que segue vigente até o presente momento.

“Com o advento da Lei 11.105/2005, que revogou expressamente a Lei 8.794/1995, a matéria obteve um tratamento jurídico nitidamente superior - mais amplo e completo - ao da legislação antecedente, com várias inovações importantes" (PRADO, 2019, p. 356). Além de prever a responsabilidade civil e administrativa, a referida lei ainda introduziu seis tipos penais ao ordenamento jurídico pátrio, o que revela a intenção do legislador de se utilizar do ramo mais gravoso do direito para fornecer efetiva proteção à biossegurança e ao patrimônio genético brasileiro. "Tem-se, portanto, como relevante, a ingerência penal no campo da biossegurança, da biotecnologia e da engenharia genética (técnicas de engenharia genética)" (PRADO, 2019, p. 368).

Dentre os tipos penais previstos pela Lei $\mathrm{n}^{\mathrm{o}} 11.105 / 05$, destaca-se a conduta contida no artigo 27 da referida lei, que tipifica o delito de liberação ou descarte de OGM no meio ambiente, em desacordo com as normas estabelecidas pela CTNBio e pelos órgãos e entidades de registro e fiscalização. "O bem juridicamente protegido pela norma penal incriminadora é o meio ambiente". (VARELLA, 1998, p. 211). Prado (2019, p. 380) defende, ainda, que o referido tipo penal tutela, alternativamente, a vida e a saúde dos ser humano do ponto de vista da biossegurança.

Trata-se de crime comum, cujo sujeito ativo pode ser qualquer pessoa. De outro lado, em razão da tutela do ambiente, tem-se a coletividade como sujeito passivo da infração penal em comento.

Os elementos objetivos do tipo consistem nas condutas de liberar ou descartar OGM no meio ambiente, em desacordo com as normas estabelecidas pela CTNBio e pelos órgãos e entidades de registro em fiscalização. Liberar pode ser compreendido como tornar livre, dispensar algo, enquanto descartar denota a ideia de rejeitar algo, jogar fora após o uso. "A liberação compreende a finalidade de que os OGMs interajam com o ambiente; o descarte, de 
seu turno, não abrange tal escopo: é o mero ato de se livrar de organismos que não tenha mais nenhuma utilidade." (PRADO, 2019, p. 383).

Contudo, não basta a liberação ou o descarte de OGM no meio ambiente para configurar o delito do artigo 27, é necessário que a liberação ou o descarte sejam realizados em desconformidade com as normas estabelecidas pelos órgãos e entidades responsáveis pelo registro e fiscalização desse tipo de organismo.

Trata-se, portanto, de norma penal em branco, diante de sua necessidade de complementação por parte de outro dispositivo legal. ${ }^{3}$ No caso, esta complementação se dá por meio de instruções normativas elaboradas pela CTNBio, como, por exemplo, a Instrução Normativa CTNBio $\mathrm{n}^{\circ}$ 10, de 19 de fevereiro de 1998, “que estabelece normas simplificadas para liberação planejada no meio ambiente de vegetais geneticamente modificados que já tenham sido aprovados pela CTNbio" (PESSOA, 2009, p. 65).

Os verbos nucleares empregados revelam tratar-se de crime formal ou de mera conduta, sendo prescindível a ocorrência de um resultado para consumação do delito. Todavia, caso algum dano decorrente da liberação ou descarte de OGM seja produzido em propriedade alheia, no meio ambiente, na integridade física ou resulte na morte de outrem, estarão configuradas as causas de aumento de pena previstas no $\S 2^{\circ}$ do artigo 27.

Por se tratar de delito que independe da verificação de um resultado lesivo para consumação, a conduta tipificada no artigo 27 retrata um crime de perigo abstrato, no qual a gravidade da conduta é presumida, sendo desnecessária a sua demonstração concreta. Tal característica será objeto de crítica no próximo capítulo.

O elemento subjetivo do tipo é o dolo, consistente na consciência e vontade de praticar as condutas descritos no tipo penal. Não se admite modalidade culposa no delito em questão, diante da ausência de previsão legal neste sentido, nos termos do parágrafo único do artigo 18 do Código Penal ${ }^{4}$. Não se admite a tentativa para o delito em questão.

\footnotetext{
${ }^{3}$ Três são as formas apresentadas para o preenchimento ou complementação da lacuna constante da normal em branco: 1) o complemento se acha contido na mesma lei (refere-se mais a um problema de técnica legislativa deficiente, em geral); 2) o complemento se acha contido em outra lei, mas emana do mesmo poder; 3) o complemento se acha contido em disposição normativa de outro poder - essas serias as leis penais em branco em sentido estrito. (PRADO, Luiz Regis. Direito penal do ambiente: crimes ambientais (Lei 9.605/1998). 7 ed. Rio de Janeiro: Forense, 2019, p. 37).

${ }^{4}$ Art. 18 - Diz-se o crime: (Redação dada pela Lei no 7.209, de 11.7.1984)

(...)

II - culposo, quando o agente deu causa ao resultado por imprudência, negligência ou imperícia. (Incluído pela Lei $\mathrm{n}^{\circ} 7.209$, de 11.7.1984)
} 
A pena do crime é de um a quatro anos de reclusão e multa, sendo que a pena poder ser aumentada de 1/3 até o dobro caso ocorra alguma das situações previstas nos incisos do $\S 2^{\circ}$ do artigo 27.

Por fim, trata-se de crime de ação penal pública incondicionada, cuja competência de julgamento poderá ser tanto da Justiça Estadual quanto da Justiça Federal, a depender da situação, cabendo ao Ministério Público Estadual ou Federal oferecer a denúncia contra o sujeito ativo do delito. Diante da pena mínima de um ano cominada, será possível o oferecimento da suspensão condicional do processo, bem como a celebração de acordo de não persecução penal, desde que preenchidos os requisitos do artigo 89 da Lei no 9.099/95 e/ou artigo 28 do Código de Processo Penal, respectivamente.

\section{DO BEM JURÍdiCO TUTELAdO E A AUSÊNCIA DE LESÃO EFETIVA PARA CONFIGURAÇÃO DO DELITO: VIOLAÇÃO AO PRINCÍPIO DA OFENSIVIDADE E ADMINISTRATIVIZAÇÃO DO DIREITO PENAL}

Feita a classificação doutrinária do artigo 27 da Lei $\mathrm{n}^{\circ}$ 11.105/05, cumpre a este artigo tecer algumas críticas acerca das escolhas feitas pelo legislador ao tipificar a conduta analisada, uma vez que a redação empregada evidencia uma tendência cada vez mais comum do legislador brasileiro de criminalizar condutas independente do resultado. Ademais, recorrer ao uso de normas penais em branco, que constantemente são integradas por meio de atos normativos administrativos, o que caracteriza o fenômeno conhecido por administrativização do direito penal.

Conforme mencionado no tópico anterior, o delito do artigo 27 é considerado um crime formal de perigo abstrato, ou seja, independe da produção de um resultado naturalístico para consumação do crime, sendo suficiente a prática de um dos verbos nucleares descritos no tipo, pouco importando a ocorrência de uma lesão ao bem jurídico tutelado. É, ainda, prescindível a demonstração do perigo decorrente da conduta praticada, uma vez que esse é presumido legalmente, o que vai na contramão do princípio da ofensividade, que estabelece que "é indispensável que haja, pelo menos, um perigo concreto, real e efetivo de dano a um

Parágrafo único - Salvo os casos expressos em lei, ninguém pode ser punido por fato previsto como crime, senão quando o pratica dolosamente. (Incluído pela Lei $\mathrm{n}^{\circ} 7.209$, de 11.7.1984) 
bem jurídico penalmente protegido", para que a conduta possa ser tipificada. (BITENCOURT, 2012, p. 111).

"Partindo desse fundamento, pode-se dizer que o bem jurídico é um dado relacionado à pessoa humana, como seu elemento de preferência e orientação, o qual adquire valor quando incorporado à respectiva norma de conduta, proibitiva ou mandamental" (TAVARES, 2020, p. 97). "Na atualidade, é pacífico o entendimento de que todo delito comporta uma lesão ou ameaça de lesão a um bem jurídico (princípio da lesividade ou ofensividade)" (PRADO, 2019, p. 358). Sendo assim, a principal função do Direito Penal consiste na tutela dos bens jurídicos primordiais para a sociedade e o indivíduo, sempre vinculado a ideia de proteção à dignidade da pessoa humana como forma de legitimação da escolha do bem jurídico para ser tutelado pela ultima ratio do ordenamento jurídico.

Inegável, portanto, que o meio ambiente representa um bem jurídico essencial para efetivação da dignidade da pessoa humana e, por conseguinte, enseja a proteção por parte do Direito Penal contra as lesões mais graves a este bem jurídico. Contudo, não parece adequada a intervenção punitiva quando não demonstrado concretamente o perigo ao bem jurídico tutelado por parte da conduta tipificada, pois "somente se justifica a intervenção estatal em termos de repressão penal se houver efetivo e concreto ataque a um interesse socialmente relevante, que represente, no mínimo, perigo concreto ao bem jurídico tutelado." (BITENCOURT, 2012, p. 111).

O princípio da ofensividade exige uma alteração mínima da realidade por parte da infração penal, o que não acontece nos delitos de perigo abstrato, como é o caso do artigo 27 da Lei $n^{\circ} 11.105 / 05$, no qual há presunção legal de perigo na realização dos verbos nucleares do tipo. Tal fato revela uma contradição com a própria estrutura dos delitos, uma vez que:

a exigência da fórmula de um perigo concreto ao bem jurídico e não um estado de simples ameaça constitui o alicerce de uma teoria crítica do delito, a qual não deve se preocupar em legitimar a intervenção penal, mas, sim, em traçar limites rigorosos à sua execução. (TAVARES, 2020, p. 90).

Portanto, a criação de crimes de perigo abstrato gera "o risco de que o Direito Penal se transforme num instrumento acessório, ou que desempenhe função que possa ser perfeitamente atribuível a outro ramo do direito (v.g., Direito Administritvo)" (PRADO, 2019, p. 364). 
O que acontece no caput do artigo 27 é a criminalização de atos meramente administrativos, ou seja, a tutela penal é voltada, tão somente, para condutas de cunho administrativo definidas previamente por órgão diverso daquele que possui legitimidade para legislar sobre matéria penal. Não se vê uma efetiva proteção ao bem jurídico, em tese, selecionado pela norma, mas sim a condutas de caráter administrativo, que, muitas vezes, não representam uma lesão ou perigo de lesão ao meio ambiente.

Não parece adequada a intervenção punitiva estatal no caso de um descarte de OGM incapaz de produzir qualquer lesão ou perigo de lesão ao meio ambiente, pelo simples fato de a conduta ter sido realizada sem a observância de alguns dos requisitos de uma instrução normativa editada pela CTNBio. É possível que o descarte, mesmo não tendo observado parte dos requisitos previstos, possa ser suficiente para evitar qualquer lesão na forma em que foi realizado, o que evidencia a desproporcionalidade do ato criminalizado por instrução normativa e a liberdade do sujeito. "A relevância de se exigir a personalização do bem jurídico está no sentido de delimitar o poder de punir, de tal modo que uma lesão ao Estado só possa ser legitimada em uma democracia quando implicar também uma violação de bem jurídico pessoal.” (TAVARES, 2020, p. 96).

Sendo assim, o Direito Administrativo se mostra um ramo mais adequado e proporcional para coibir as condutas que desrespeitem instruções normativas elaborados pela CTNBio, mas que sejam insuficientes para provocar uma lesão ou perigo de lesão ao bem jurídico tutelado pela norma penal, evitando, assim, intervenções desproporcionais por parte do Direito Penal.

\section{CONSIDERAÇÕES FINAIS}

O meio ambiente como bem jurídico constitui um acerto por parte do legislador constituinte e ordinário, diante de sua importância para concretização do princípio da dignidade da pessoa humana, um dos principais fundamentos da República Federativa do Brasil, conforme previsto no artigo $1^{\circ}$, inciso III, da Constituição da República de 1988.

A importância desse bem jurídico, entretanto, não pode servir de entrave para o avanço da biotecnologia, especialmente no tocante aos organismos geneticamente modificados, que constituem importante meio para solucionar o problema da produção de alimentos pelo mundo. Todavia, assim como qualquer atividade empresarial, a produção de 
OGMs cria riscos para a coletividade, sendo que esses riscos podem provocar lesões aos bens jurídicos existentes, ensejando, assim, a intervenção do direito.

Diante do mandamento constitucional e da necessidade de tutelar os riscos inerentes ao uso de OGMs, a Lei $n^{\circ} 11.105 / 05$ foi elaborada para regular a utilização de organismos geneticamente modificados, orientando-se pela necessidade de preservação do meio ambiente e, por conseguinte, da sociedade como um todo. A importância do tema fez com que a referida lei introduzisse, ainda, seis tipos penais relacionados às atividades envolvendo a produção de OGMs, recorrendo ao ramo mais gravoso do Direito como forma de coibir, em tese, as condutas mais graves que pudessem lesionar o bem jurídico objeto da lei.

Dentre os tipos penais previstos, o delito contido no artigo 27 foi objeto de análise deste artigo, no qual se constatou que as condutas tipificadas no caput são fruto de técnica legislativa voltada para tipificação de crimes de perigo abstrato. Dessa forma, dispensa-se a demonstração concreta de lesão ou perigo de lesão ao bem jurídico tutelado, em manifesta violação ao princípio da ofensividade, bem como se valendo do fenômeno da administrativização do Direito Penal, por meio de norma que necessita de complementação dada por ato normativo diverso de lei.

Ao final do artigo, percebeu-se que as condutas tipificadas no caput do artigo 27 representam a criminalização de atos meramente administrativos, sem a devida demonstração da lesão ou do perigo de lesão ao bem jurídico tutelado. Sendo assim, evidencia-se a desproporcionalidade do uso do Direito Penal em uma situação que pode ser resolvida pelo Direito Administrativo.

\section{REFERÊNCIAS}

BITENCOURT, Cezar Roberto. Tratado de direito penal: parte geral, 1. 17. ed. rev., ampl. e atual. de acordo com a Lei n. 12.550, de 2011. - São Paulo: Saraiva, 2012.

BRASIL. Lei 12.305, de 2 de agosto de 2010. Institui a Política Nacional de Resíduos Sólidos; altera a Lei no 9.605, de 12 de fevereiro de 1998; e dá outras providências. Disponível em: < http://www.planalto.gov.br/ccivil_03/_ato2007-2010/2010/lei/112305.htm>. Acesso em: 25 de jun. de 2021.

BRASIL. Ministério da Ciência, Tecnologia, Inovações e Comunicações. Resolução no 18, de 23 de março de 2018. Disponível em: < https://www.in.gov.br/materia//asset_publisher/Kujrw0TZC2Mb/content/id/7889749/do1-2018-03-26-resolucao-n-18-de-23de-marco-de-2018-7889745>. Acesso em: 25 de jun. de 2021. 
CAPALBO, Deise M.F. et al. OGM e biossegurança ambiental. 2009. Disponível em: <https://www.alice.cnptia.embrapa.br/bitstream/doc/579757/1/2009CL11.pdf >. Acesso em: 25 de jun. de 2021.

CASABONA, Carlos. O direito biomédico e a bioética. In: Casabona, Carlos Maria Romeu, Queiroz Juliane, coordenadores. Biotecnologia e suas implicações ético-jurídicas. Belo Horizonte: Del Rey; 2005. p. 13-44.

FABRIZ, Daury Cesar. Bioética e direitos fundamentais. Belo Horizonte: Mandamentos; 2003. p. 288. 24.

FERRER, Jorge Jose, Álvarez Juan Carlos. Para fundamentar a bioética. São Paulo: Loyola; 2005. p. 69. 4.

NAVES, Bruno Torquato de Oliveira; SILVA, Marcela Vitoriano e. Organismos geneticamente modificados sob a perspectiva da tutela das gerações futuras. Veredas do Direito, Belo Horizonte, v.11, n.22, p.355-380, Julho/Dezembro de 2014. Disponível em: <file:///C:/Users/henri/Downloads/473-Texto\%20do\%20Artigo-2288-1-10-20150826.pdf>. Acesso em 25 de jun. de 2021.

OLIVEIRA, Gustavo Paschoal Teixeira de Castro. Política Nacional de Biossegurança: contribuições bioéticas para com a comercialização e consumo de organismos geneticamente modificados ante o principio da precaução. Tese (Doutorado em Direito. Pós-Graduação Stricto Sensu em Direito, Centro Universitário de Brasilia - UniCEUB. Brasília, 2016.

PESSOA, Flávia Moreira Guimarães. Bioética e Direito Penal: a questão dos transgênicos. In: Costa, Marco Antonio F. da Biossegurança de OGM: uma visão integrada / Marco Antonio F. da Costa e Maria de Fátima Barrozo da Costa. - Rio de Janeiro: Publit, 2009

PRADO, Luiz Regis. Direito penal do ambiente: crimes ambientais (Lei 9.605/1998). 7 ed. Rio de Janeiro: Forense, 2019.

SÁ, Maria de Fátima Freire de; NAVES, Bruno Torquato de Oliveira. Manual de biodireito. $5^{\text {a }}$ ed. Belo Horizonte: Del Rey; 2021. p. 9.

SANTOS, Maria Celeste Cordeiro L., organizadora. Biodireito: ciência da vida, os novos desafios. São Paulo: Revista dos Tribunais; 2001. p. 120-1

SILVA, Letícia Rodrigues da; PELAEZ, Victor; Valle, Silvio. Implementação da Lei de Biossegurança no Brasil. In: Costa, Marco Antonio F. da Biossegurança de OGM: uma visão integrada / Marco Antonio F. da Costa e Maria de Fátima Barrozo da Costa. - Rio de Janeiro: Publit, 2009

TAVARES, Juarez. Fundamentos de teoria do delito. 1.ed. - Florianópolis: Empório do Direito, 2018.

VARELLA, Marcelo Dias. FONTES, Eliana. Galvão, Fernando. Biossegurança e biodiversidade: contexto científico regulamentar. Belo Horizonte: Del Rey, 1998. 